\title{
Henricus Jacobus Maria Weve
}

It is interesting to appreciate how great has been the contribution to the accumulated riches of ophthalmology given by the smaller countries of Europe. Among these, Holland has been outstanding; this would be expected in the land which in a previous century, when modern medicine was in its infancy, produced world-famous figures of the calibre of Boerhaave and Ruysch, and a genius like van Leeuwenhoek. In all Holland no centre of learning has excelled Utrecht in its gifts to ophthalmology. This quiet and dignified university city has indeed been a nursery of great ophthalmological figures - Jan Mulder and van der Kolk, and in the Chair of Ophthalmology, Donders (1858-1883), the two Snellens (1883-1903; 1903-1928), and, until now, Weve. '

On April 19th this year Weve reaches his 70th birthday; and it is only fitting that a tribute should be paid to him, more particularly in the Journal he has done so much to foster. The entire family of ophthalmologists throughout the world will be proud to associate itself with this, for in his long and immensely fruitful professional life Weve has given of his best, wholeheartedly and unstintingly, to our specialty-and his best has been very good indeed. Moreover, in his relationships with his colleagues in many lands none is a kinder friend or a better companion. Born in Nijmegen in 1888, he went to school at Aloysius College in that city, graduating therefrom in 1906; thereafter he pursued his medical studies at the University of Amsterdam from which he graduated in 1912. He then became an assistant in Straub's Eye Clinic at Amsterdam, and subsequently at Würzburg. The outbreak of the Eirst World War, however, disturbed the normal course of his ophthalmological apprenticeship, and at its commencement in 1914 he joined the Royal Dutch Army, retaining his attachment thereto until its end in 1918. In the meantime, in 1916, he became the first surgeon in the Ophthalmic Clinic in Rotterdam, and from this centre produced his Doctor's Thesis on the subject of "Keratitis urica and other forms of gouty ophthal-

234

Henricus Jacobus Maria Wove

mological diseases". It was a masterly work wherein rare corneal appearances, little understood or appreciated at the time, were for the first time correlated into an integrated picture; this and a number of other papers, all indicating unusual powers of clinical observation, secured his election to the Chair of Ophthalmology in Utrecht in 1929. His association with this University has remained unbroken until the present time, although the even tenor of its academic life was sadly disrupted by the turbulent events which disorganized life in Holland during the Second World War when the German army occupied Holland. After the war, in recognition of his scholastic and administrative ability, the University elected him to serve as Rector Magnificus (1949-50), a post which he held at a difficult period with great distinction.

These are the main outlines of Weve's academic life-an ideal life such as most of us would wish if the stresses, the unhappiness and the privations of the years between 1940 and 1945 could have been eliminated. But the academic setting of Utrecht did not inhibit the enthusiasm of one of the greatest workers in ophthalmology in his ceaseless and life-long endeavour to advance the 
knowledge of his subject. Possessed of unusual industry and blessed with a clinical acumen and powers of observation above the ordinary, he has contributed continuously and richly to ophthalmic literature during the long years of his professional life. Equally endowed with operative skill combined with the originality of mind and spirit of adventure which fitted him to devise new techniques, he has come to be recognized as one of the first ophthalmic surgeons in Europe; in this capacity he has attracted to his clinic difficult cases from all over the world. Frequently when others admitted failure in such cases, he succeeded. A close friend of Gonín, he was one of the first to apply the new technique introduced by the great Swiss ophthalmologist in the treatment of retinal detachment, and has done much to improve it; he was a pioneer in the operation of cyclodiathermy, and more recently in the treatment of intra-ocular neoplasms by diathermy and radiation. These are but a few highlights in a professional career which has been excelled by few.

It is obvious that this record has been acclaimed in his own and other countries. In his own country he was made a member of the Royal Dutch Academy of Science, and President of the Dutch Ophthalmological Society. He was elected an honorary

Henricus Jacobus Maria Weve

235

member of the Royal Flemish Academy of Medicine, the Royal Society of Medicine (London), the American Academy of Ophthalmology and Otolaryngology, the International College of Surgeons, and of the Ophthalmological Societies of the United Kingdom, of Belgium, of America, of Greece and Northern Greece, and of Australia. The Ophthalmological Society of the United Kingdom paid him the highest tribute in their power in 1939 by awarding him the Bowman Medal, an occasion on which his Bowman Lecture, "On diathermy in ophthalmic practice", was one of the best in that long series of distinguished lectureships. In Ireland he was invited in 1951 to give the Montgomery Lecture; and in 1952 he gave the Montpellier Lecture. Because of his international reputation not only as an ophthalmologist but as a wise and understanding statesman, he was elected in 1954 to the International Council of Ophthalmology; and because of his professional ability and his unique position in his own country, he has long carried the responsibility of acting as oculist to the Royal House of Holland.

Thus Weve the ophthalmologist: how about Weve the man? I met him first at that delightful reunion of ophthalmology after the First World War, at the International Congress in Holland in 1929; next, when he invited me to the Dutch Ophthalmological Society in 1930 . For over a quarter of a century I have known him intimately; he has stayed at my home, and I at his; we have seen each other at work. There is no colleague throughout the world whom I admire more; nor any for whom 1 have a greater affection. Few do I meet with greater anticipation; none do I leave with greater regret. With his knowledge and astute critical faculty, few can give a wiser cpinion of recent advances in ophthalmology; full of kindliness and sincerity, brimming over with a puckish sense of humour and a prolific purveyor of good stories, none is a more delightful companion; with his transparent honesty and integrity, none can be trusted more. Never have I heard him-even on provocation-say a disparaging word of anyone. Nor am I alone in my assessment. On his recent journeys to other countries-to America, to India, to Africa, and to Australia-he left behind him a warm memory, not only of a wise and mature ophthalmologist, but of a human being whose enthusiasm for life generally, for photographing birds or gathering flowers, for assimilating the spirit of a community, and for en236

Henricus Jacobus Maria Weve 
thralling-and amusing-a gathering in an after-dinner speech, is equalled only by the bigness of his humanity. At the centenary meeting of the German üphthalmological Society in Heidelberg last year, his oration at the banquet (in German, for he speaks and writes 4 or 5 languages with equal facility) was great in its content, in the spirit of its magnanimity, and quite certainly the best at that meeting.

Stewart Duke-Elder.

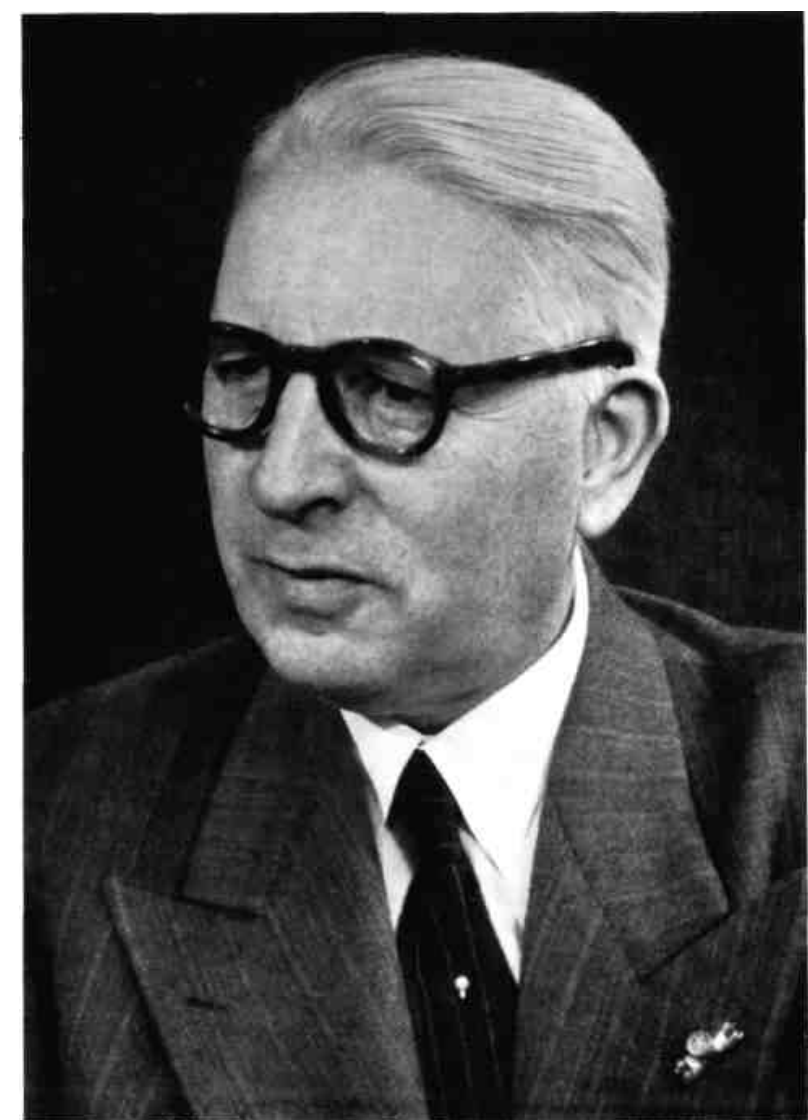

Jtü"- W. Weve is now 70

years of age; but he is still well and active. He emerged-white-haired and emaciated it is true-after the anxieties and privations of a war-time spent with honour in an enemyoccupied country; but with unusual resiliency he never lost the good humour for which we all love him. Unusually blessed and happy in his family life surrounded by friends in the quiet atmosphere of his beloved city of Utrecht his colleagues from every country in the world send 